\title{
Fantasin som medel att bearbeta rädslor - En stackars liten haj och bilderbokens unika förutsättningar
}

\author{
Emma Tornborg
}

I följande artikel kommer jag att analysera bilderboken En stackars liten haj (2014) av Mårten Sandén och Per Gustavsson ur ett par olika perspektiv, för att undersöka hur den gestaltar ett litet barns bearbetning av rädsla med hjälp av fantasin, och hur den, både verbalt och med hjälp av bilderna, kan få sina unga läsare att identifiera sig med huvudpersonen, känna empati för honom och därmed själva gå stärkta ur läsupplevelsen. För att göra detta kommer jag bland annat att närmare studera hur ord och bild samverkar i boken samt de olika tolkningsnivåer och intertextuella relationer man kan finna i den.

\section{Fantastik i barnlitteraturen}

Även om det i olika tider har funnits olika uppfattningar om vad barnbokens syfte bör vara, så har barnlitteraturen i praktiken för det mesta haft en dubbel funktion - förutom att roa sina unga läsare har den också lärt dem någonting. Barnlitteratur, särskilt den riktad mot yngre barn, har med andra ord för det mesta haft ett didaktiskt inslag, den är och har varit instrumentell på ett sätt som vuxenlitteratur inte är. Från och med mitten av 1900-talet har det visserligen skett en förändring när det gäller tilltal (address), ett begrepp som Barbara Wall diskuterar i samband med barnlitteratur:

Contemporary criticism has not yet adjusted to the fact that the mode of address in fiction for children which emerged in the first half of the century and which is common today, a mode of address which I have called single address, is different in kind from the prevailing mode used by writers in the Victorian era. This earlier mode I have termed double address. An understanding of this difference, of the significance of the gradual disappearance of an adult narrative voice which exhibited strong consciousness of the presence of adult readers and its replacement by a voice concerned more genuinely and specifically with child readers, is a prerequisite for understanding contemporary attitudes to fiction for children. Narrators using single address, double address, or a fusion of the two, dual address, can be shown to speak respectively to single, double or dual audiences. (1991: 9)

Istället för att tala till barnet talar den moderna barnboken med det, det finns en ömsesidighet och en respekt för den unga läsaren som speglar den nya barnsyn som växte fram under 1900talet. Detta faktum hindrar inte att barnlitteratur ofrånkomligen till sin natur ändå är ojämlik: relationen mellan sändaren (författaren och i viss mån den högläsande föräldern, som ju också fungerar som mottagare) och den primära mottagaren, barnet, är ju inte en jämlik sådan, hur mycket författaren än anstränger sig att lägga sig på barnets nivå. Barnlitteraturen är alltid uttryck för en maktrelation som präglas av obalans, vilket inte är så konstigt men ändå inte bör glömmas bort när man studerar barnlitteraturen och dess uttryck. 
En funktion som barnboken kan ha är att hjälpa barnet att bearbeta sådant som kan vara besvärligt i livet: övergivenhet, skilsmässa, mobbing och rädsla för allt från döden till spöken och liknande. I det verk som ska undersökas närmare här - En stackars liten haj (2014) av Mårten Sandén och Per Gustavsson - fungerar fantasi-anslaget som en katalysator för den största rädslan men utgör även en bearbetningsprocess som i slutändan befriar protagonisten från det som trycker honom.

Om en berättelse börjar i en vanlig, realistisk värld - vår värld - för att sedan gå över i en annan värld med mystiska och övernaturliga inslag, så har vi ofta att göra med en fantasyhistoria. Det finns ett otal exempel på sådana övergångar, det räcker med att tänka på Astrid Lindgrens Mio min Mio och Bröderna Lejonhjärta, C. S Lewis Narnia-böcker eller J. K Rowlings Harry Potter-serie. När det gäller riktigt små barn sker övergången oftast i en dröm, en dagdröm eller liknande, beroende på små barns begränsade möjlighet att ta sig någonstans på eget initiativ. Maria Nikolajeva skriver: "Eftersom bilderböcker, åtminstone formellt, riktar sig till mycket små barn, används ofta drömmen som det magiska medlet för att skildra övergången”. (2000:52) Boel Westin skriver specifikt om dagdrömmar och kallar texter som härrör ur dessa "drömtexter”: "Dessa vakna drömmar kallar jag i det följande för 'drömtexter'. I barnlitteraturen hör de främst hemma i berättelser som spelar med två (eller flera) dimensioner inom fiktionen: en 'verklig' dimension och en 'fantastisk' dimension som samverkar med varandra”. (2008:71) Precis så är En stackars liten haj uppbyggd (även om det verkligen kan diskuteras om den bör karakteriseras som fantasy i vanlig mening): den fantastiska dimensionen släpper aldrig helt taget om den realistiska dimensionen, i hela det fantastiska äventyr som pojken upplever så finns det hela tiden kopplingar tillbaka, till pojkrummet och till vardagen, vilket vi ska se.

\section{Äventyret}

I En stackars liten haj får vi möta en pojke som är fruktansvärt rädd för hajar: ”Pojken var rädd för hajar nästan jämt. Han kikade efter hajar under sängen. När han satt på toaletten var han rädd för att en haj skulle bita honom i rumpan” (andra uppslaget, vänster sida). Uppslagets vänstra sida visar en badrumsinteriör med ett vattenfyllt badkar och en toalett. Pojken står på toalettringen och spanar ner i hålet. På högersidan är vi inne i pojkens rum. Över hans blåa säng syns en skugga av en haj, som liksom förvandlar sängen till en haj med ögon och tänder. Den blå mattan vågar sig och en hajfena sticker upp ur den. Texten lyder: "Pojkens mamma berättade att hajar bara finns i varma hav, men det hjälpte inte. Pojken var rädd för dem i alla fall.” 


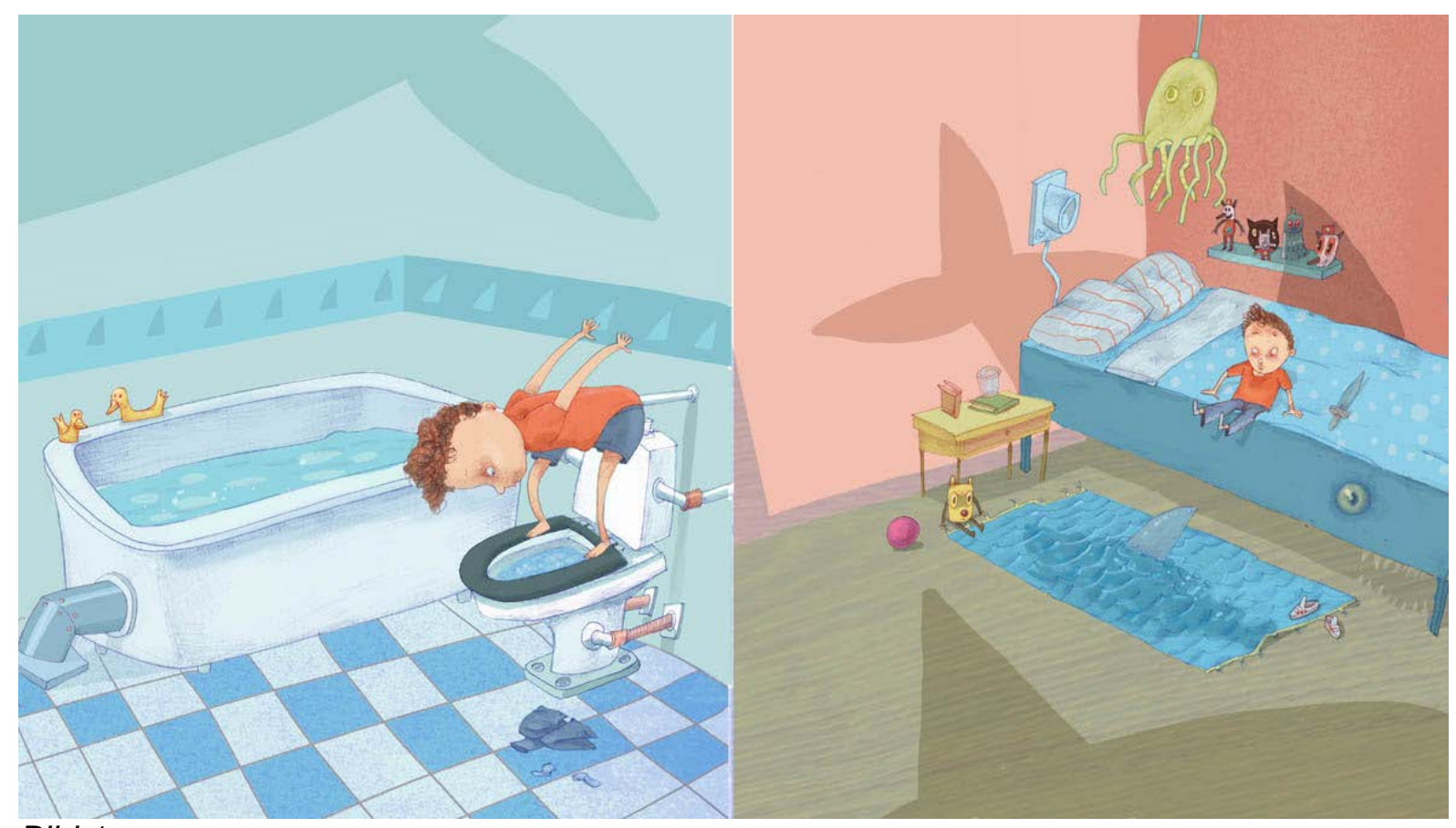

Bild 1

Maria Nikolajeva påpekar att "[c]hildren’s picturebooks are normally treated as a separate category, while in fact some of them not only display characteristic features of fantasy, but provide vast possibilities for the hesitation that lies at the basis for the fantastic" (2012:59) . Det blir tydligt just i pojkrumsscenen där texten inte nämner något om hajarna som hemsöker rummet. Man förstår att de inte är verkliga utan är ett uttryck för pojkens rädsla, men de skapar ändå en hotande atmosfär som texten i sig inte förmedlar. Bilderna gör det tydligt att pojkens rädsla hänger över honom hela tiden och att han aldrig får känna sig trygg. Rhedin diskuterar bilderbokens förmåga att visualisera känslor i samband med Tove Janssons bilderbok Den farliga resan: ”De kan genom sina olika kompositionella betoningar på instängdhet, ödslighet, eruptiva utbrott, regn eller piskande snöstorm sägas spegla de psykiska förloppen hos huvudpersonen, något som påminner om den expressionistiska konstens utvändiggörande av inre förlopp” (2001:162). På samma sätt fungerar alltså hajskuggorna: De visar på ett konkret sätt hur pojkens skräck är beskaffad.

Nikolajeva diskuterar bilderbokens betydelse för barns känslomässiga utveckling: ”Young children may not know exactly what the verbal phrases 'He was sad' or 'She was frightened' mean, yet they will presumably respond to the visual representation of sadness or fear" (2013: 251). Hon exemplifierar med att munnens form är en tydlig signal på hur den avbildade karaktären känner sig: glad, ledsen, förvånad, arg och så vidare. Även ögonens form ger tydliga signaler: "Wide-open eyes signal either surprise or fear” (251). I bilden kan vi se hur pojkens ögon är uppspärrade när han tittar efter hajar i toaletten eller oroar sig för att de finns under sängen.

En annan sak som bilden adderar till ikonotexten ${ }^{1}$ på högersidan är den stora gröna bläckfisk som hänger i taket i pojkens rum. Den visar att pojken har ett intresse för havet och dess invånare, och man kan ana att det är ur detta intresse som hajrädslan kan ha fötts.

\footnotetext{
${ }^{1}$ Ett begrepp myntat av Kristin Hallberg (1982) som betecknar "den syntes av ord och bilder som varje bilderbok består av.” (Nikolajeva 2000: 15)
} 
Samverkan mellan ord och bild på detta uppslag fungerar alltså kompletterande i enlighet med Nikolajevas typologi: "ord och bilder kompletterar varandra, fyller varandras luckor, kompenserar varandras otillräckligheter” (2000:22).

På nästa uppslag sitter pojken i badkaret för modern har sagt åt honom att han måste bada. Han får ha sitt svärd med sig och han ska ropa om det blir för otäckt. Plötsligt märker han hur bubblorna guppar fast han inte rör sig. På vänstra uppslaget tittar han under vattnet och får syn på en haj. En haj i badkaret! Pojkens värsta mardröm har besannats. Han är alldeles stel av rädsla tills han upptäcker att hajen är ännu räddare än vad han är och att den gråter efter sin mor. Den hade råkat simma in i ett rör av misstag och hamnat i pojkens badkar. Pojken bestämmer sig för att hjälpa hajen tillbaka till havet. Han stoppar hajen i en shoppingväska med vatten och salt (som hajen ber om), skriver en lapp till modern och ger sig ut i den sena kvällen för att ta sig till havet.

Från att ha varit i underläge, en liten rädd pojke mot de stora hemska hajar han har föreställt sig och som finns avbildade både på första och andra uppslaget, blir pojken nu den stora och starka, som ska rädda en mycket liten haj från ödet att ha hamnat i hans badkar. Rollerna är därmed helt ombytta. Westin skriver:

Genom drömtexten kan den som drömmer, vanligen huvudpersonen (protagonisten), omtolka och omformulera sin verklighet inom fiktionen. Han eller hon skapar en "drömtext", en berättelse i fantasin som för drömmaren får en förvandlande kraft. Den står för en övergång från ett tillstånd till ett annat. Drömmarna är förknippade med en längtan efter förändring och i förlängningen med en individuell pånyttfödelse - en utforskning av det egna jaget (2008:71).

I denna del av det som vi förmodar är en dagdröm har pojken tagit kommandot över sin rädsla och blivit styrkt av det. Nu har han kontrollen, och omvandlingsprocessen har börjat.

Den nattliga stadens karaktär är intressant: ”Pojken hade aldrig varit ute ensam så här sent” (sjätte uppslaget). Det är pojkens föreställningar om den nattliga staden som visualiseras i de kommande uppslagen. Staden är full av mysterier, märkliga varelser och antropomorfiserade djur. Man ser personer som bär på olika sorters vattenlevande djur, bland annat en flicka med en bläckfisk i en skottkärra. Hon dyker upp på flera uppslag boken igenom. Pojken verkar således inte vara den ende som har fått besök från havet. Ett annat återkommande inslag är två flickor som bär på varsin stor ballong. 


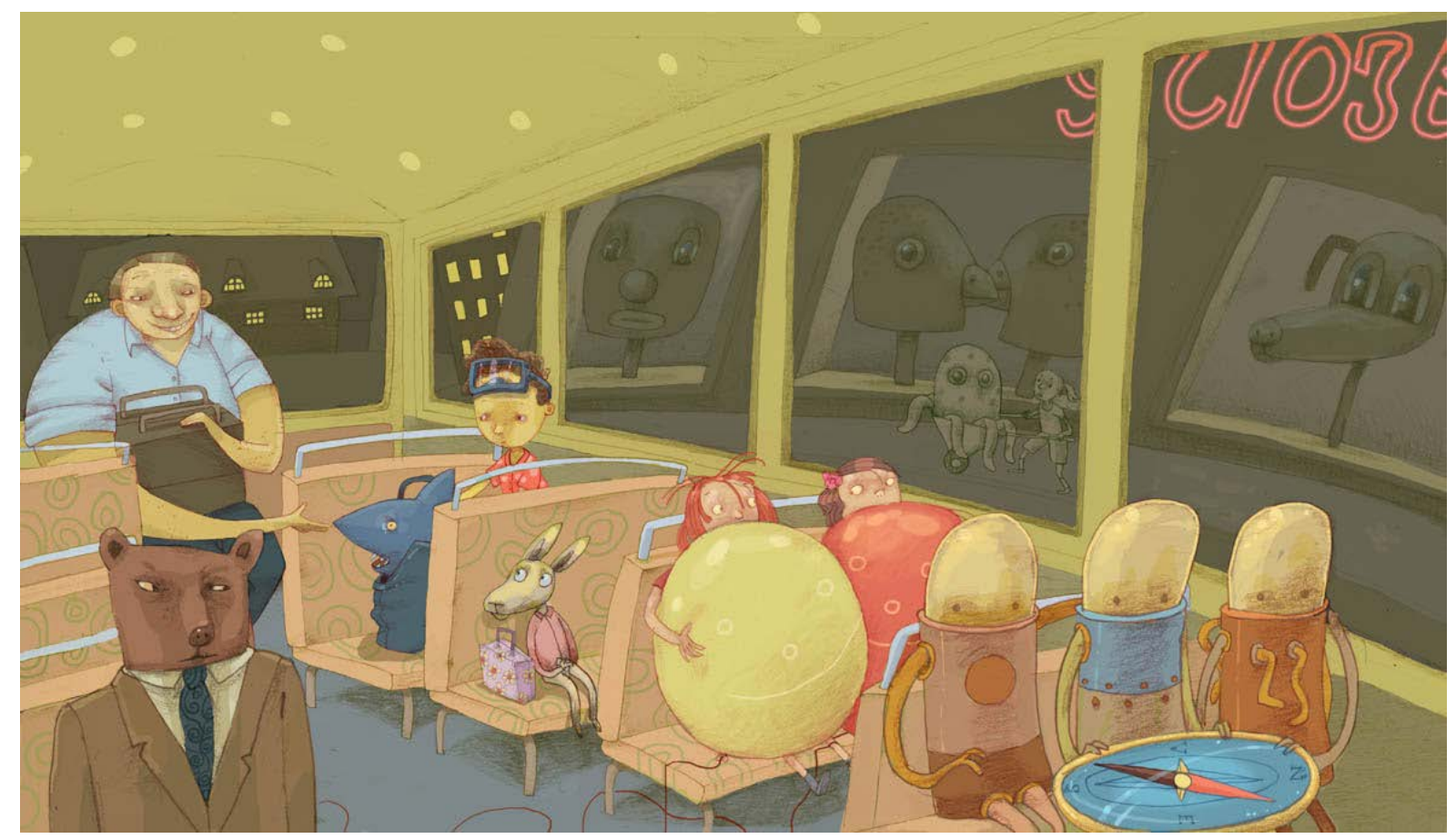

Bild 2

Bilden ovan (åttonde uppslaget) visar pojkens bussfärd med hajen i en vattenfylld väska. Mannen längst bak är den tredje personen som pojken interagerar med på sin resa (de föregående är en man i en tidningskiosk och en taxichaufför). Dessa tre män kallar honom alla "lilleman” och de två första frågar honom om han har hällt salt i vattnet. De ger honom goda råd om hur han ska ta sig till havet: Den första påpekar att det är långt bort, den andra talar om för honom att det blir för dyrt med taxi och att han bör ta bussen och den tredje uppmanar honom att gå av vid Vattenverket för att få veta var exakt hans badkarsrör rinner ut i havet. De fungerar med andra ord som ett slags vägvisare, eller, med Vladimir Propps morfologi (Propp 1994: XXX, introduktion), hjälpare, som leder pojken framåt på hans uppdrag. Det är intressant att notera att alla tre är män, medan både starten på äventyret (hemmet) och målet för det (havet) domineras av en moders närvaro (först pojkens och sedan hajens).

Jag kommer att tänka på Astrid Lindgrens konstsaga ”I Skymningslandet” när jag läser om pojkens upplevelser och möten i staden. Precis som hos Lindgren är staden om kvällen en annan än om dagen, till och med befolkad av andra varelser än dem som lever där på dagen. Kvällen, hos Lindgren skymningstimmen, är en magisk plats där tid och rum hänger samman på ett oupplösligt sätt: En kort stund blir platsen en annan och märkliga saker kan hända. Maktlösa barn kan plötsligt flyga, köra spårvagn och manövrera grävskopor. Hos Sandén och Gustavsson kan en liten pojke ge sig ut i natten och ta sig till havet med en haj i sin väska och lyckas återbörda honom till sin hajmoder.

Det är intressant att jämföra denna sorts nattskildring, där fantasierna får vara som de är, med andra nattskildringar som går ut på att lugna barnen: det finns inget konstigt nattetid! Exempelvis i Inger och Lasse Sandbergs Tummen tittar på natten (1980) ser Tummen de underligaste saker som han tror är häxor, troll och spöken, men det visar sig alltid vara helt vanliga saker som buskar, bilar och handdukar. Samma tanke ligger bakom Jan Lööfs Pelles ficklampa (1978) där hemska saker får sin förklaring om man lyser på dem med ficklampan. 
Ett modernt exempel är flikboken Busiga bebbens nattbok (2006) av Thomas Svensson, som handlar om en flicka som är rädd för mörkret och tycker att hon ser konstiga saker, men om man lyfter på fliken så ser man att det egentligen är något ofarligt. I En stackars liten haj får det mystiska vara mystiskt, eftersom vi befinner oss i pojkens fantasi. Det är hans uppfattning om hur staden ser ut på kvällen som vi får ta del av. En bilderbok som har en liknande estetik är Aurore Jessets och Barbara Korthues Kom tillbaka, Nenne (2011). Den handlar om en flicka som har glömt sitt favoritgosedjur hos doktorn och hon föreställer sig alla hemskheter det kan bli utsatt för under natten. Den nattliga staden (som hon föreställer sig den) befolkas av en liten man på ett tak, en elak sopbil med tänder, fåglar som hänger i snören från himlen och ett litet rymdskepp med två flickor i. Stämningen i bilderna är absurd på ett sätt som påminner om den i En stackars liten haj.

Vattenverket är en labyrintisk, närmast gotisk plats med stora maskiner och konstiga varelser i glasburkar. Ingenjören som arbetar där (och som blir pojkens fjärde och sista manliga hjälpare under sitt nattliga äventyr) har sladdar som går från ryggen in i en av maskinerna. Man kan komma att tänka på exempelvis Mary Shelleys Frankenstein. Det skulle kunna vara otäckt, men hela atmosfären är snarare drömsk, magisk. Pojken får reda på exakt var hans rör mynnar ut i havet:

Ingenjören gick bort till en datamaskin och tryckte på ett par knappar.

"Som jag trodde”, sa han. ”Det blir rör 457-Tango-Adam-Foxtrot-19. Västligt.”

"Ojdå”, sa pojken. ”Hur hittar man ett sådant?"

”Det rinner ut bakom den gamla glasskiosken på stranden”, sa ingenjören. ”Över gatan, hundra meter åt vänster och sedan är ni där” (elfte uppslaget).

Efter att pojken besökt Vattenverket tar han sig till den rätta platsen och sätter sig för att tillsammans med den stackars lilla hajen vänta på hajmodern. Här, på stranden, har flera av de figurer som varit närvarande under olika delar av hans resa samlats: flickan som hade en bläckfisk i en skottkärra vinkar farväl till djuret där det försvinner ut i havet. Bläckfisken vinkar tillbaka med en av alla sina armar. De tre märkliga figurerna med en kompass som vi såg på bussen (bild 2) blir upphämtade av en rymdfarkost. De två flickornas ballonger svävar på himlen som två färgglada och leende månar. Man ser också en person som ror ut ett tvehövdat vattenodjur i en eka. På detta uppslag får bilden berätta det mesta, texten nämner bara pojken och hajen. Det blir avslutningen på flera små parallella, enbart visuella, berättelser som har pågått vid sidan av pojkens äventyr med hajen. Även om berättelserna hänger ihop med huvudhistorien - de har havet som sitt primära mål, de utspelar sig vid samma tid och plats, och åtminstone bläckfisken tillhör pojkrummets sfär (som vi minns hänger den ju i taket i hans rum) - så har sidoberättelserna alltså berättats enbart med visuella medel.

Slutligen dyker hajmodern upp och tillsammans simmar de två hajarna ut i havet. På sista uppslaget lägger sig pojken i vattnet vid strandkanten och väntar på att nattbussen hem ska gå: 
Han lade sig på rygg i det grunda vattnet. Jag har visst inte badat så mycket på sista tiden, tänkte pojken. Vad konstigt - jag som älskar att bada!

Han låg där i det ljumma, salta vattnet och tänkte på lite av varje. Han tänkte på hajar och mammor och på hur skönt det var att bada. Men att han hade varit väldigt rädd för hajar tänkte han inte alls på, för det hade han alldeles glömt bort.

På bokens sista bild får vi se pojken ligga i vattnet. Under honom avtecknar sig konturerna av ett badkar, och en bit bort simmar en badanka som vi känner igen från badrumsinteriören i början av boken. Verkligheten börjar sakta återvända, men det förmedlas enbart via bilden.

\section{Mimetisk och icke-mimetisk tolkning}

Att tolka en berättelse mimetiskt är att tolka den bokstavligt, som att det som framställs är sant. Det är det vanligaste tolkningssättet för barn, som inte har samma vana som vuxna att avkoda text (Nikolajeva 2000: 231). Det innebär inte att barn gör sämre läsningar, men de har av naturliga skäl mindre erfarenhet än vuxna av både tillvaron och litteraturen ${ }^{2}$.

Det finns olika sätt att diskutera och tolka litteratur i termer av sann och osann, bokstavlig och symbolisk. Nikolajeva använder modalitet som en term som kan användas när man avgör om texten är sann eller inte. Indikativ modalitet innebär att man tolkar texten bokstavligt, att det som står är sant. Om man gör en symbolisk läsning läser man texten snarare som att den uttrycker exempelvis möjlighet, omöjlighet, önskan, nödvändighet, antagande och osäkerhet. Text kan på olika sätt uttrycka modalitet men bilder kan inte göra det på samma sätt, menar Nikolajeva. Därför, hävdar hon innehåller bilderboken ofta intressanta motsättningar mellan ord och bild: "Images and verbal statements may be mutually complementary or enhancing; they can even be contradictory. For instance, words can state that the character is happy while the images show the character is upset. Verbal statements are more precise and concrete than images" (2013: 252).

Hur kan man tolka En stackars liten haj? Som vuxen läser man den troligtvis symboliskt, som ett sätt för pojken att med hjälp av sin fantasi bearbeta en rädsla som går ut över stora delar av hans liv (den är exempelvis inte enbart förknippad med vatten, utan pojken är rädd för hajar var han än befinner sig). För ett barn kan läsningen säkert upplevas som motstridig och därmed intresseväckande. Om man undantar inledningen och avslutningen så finns det en konsekvent berättad historia, i bilder och i ord, om en pojke som ger sig ut i natten för att ta en haj tillbaka till havet. Men de två första uppslagen förvirrar. Den allra första bilden visar pojken som står på en gräsmatta bredvid en liten damm. Han står vänd mot dammen men precis bakom honom - alltså långt borta från vattnet - tornar en enorm haj upp sig med gapet öppet. Det är inte ett särskilt trovärdigt scenario, och i kombination med bilderna på nästa

\footnotetext{
${ }^{2}$ Barnlitteraturforskaren Zohar Shavit diskuterar barnböcker som kan sägas tillhöra två litterära system samtidigt, vuxenlitteratursystemet och barnlitteratursystemet, de är med hennes språkbruk ambivalenta, eftersom "they are read differently by at least two groups of readers" (1980: 76). Hon tar Alice i Underlandet som exempel. Nikolajeva påpekar att Shavit endast räknar in ytterst få barnlitterära texter i den gruppen, och att hon är ointresserad av övrig barnlitteratur (2017: 19, 20). Andra forskare menar att ambivalensen är barnlitteraturens grundform. När jag i denna artikel talar om ambivalens avser jag inte en text som tillhör två litterära system, utan helt enkelt en text som kan förstås på olika sätt, exempelvis för att text och bild motsäger varandra, eller för att texten kan tolkas både bokstavligt och symboliskt.
} 
uppslag, där hajens skugga syns i badrumstaket och över sängen (som har hajögon och tänder) samt där en hajfena sticker upp ur mattan som har börjat våga sig och likna vatten, så tror jag inte att ens riktigt unga läsare tolkar situationen som att hajen verkligen finns där. Utan tvekan förstår barnet att det är något annat som avses än att hajen verkligen befinner sig där bokstavligen. Och i kombination med texten, som handlar om pojkens rädsla, är det inte svårt att som vuxen medläsare få in barnet på en symbolisk tolkning.

Relationen mellan den sista bilden och texten är också ambivalent. På näst sista uppslaget bekräftas det att pojken är kvar på stranden ("det var ännu en stund tills nattbussen hem skulle gå”) och på det sista uppslaget lägger han sig ner i det grunda vattnet. Varför kan man då se hans badkarskanter i vattnet? Och var kommer badankan ifrån? Nikolajeva kallar detta fenomen "dubitativ som provoceras av bilden":

Det är uppenbarligen mer spännande för bilderboksskapare att undergräva berättelsens modalitet med visuella medel, som är implicita snarare än explicita och tillåter därför ett bredare utrymme för olika tolkningar. Ett sådant visuellt undergrävande innebär att medan ikonotexten som helhet uppmanar eller tvingar läsaren att tillämpa en viss modalitet så leder några enstaka detaljer till tvekan, det vill säga provocerar fram dubitativ (2000:242f.).

Texten är tydlig med att pojken är kvar i havet, men bilden antyder något annat. Åtminstone för ett barn kan detta skapa ett dubitativ, för den vuxna medläsaren står det nog helt klart att det är pojkens badkar man ser och att han har legat där hela tiden. Men det är ändå en subtil antydan, det hade kunnat göras helt tydligt genom att avbilda ett badkar i ett badrum och pojken liggandes i badkaret. Nu blir det tillräckligt tvetydigt för att ingen tolkning ska kunna avfärdas, och därmed går det inte över huvudet på barnläsaren.

En bok som man inte kan undgå att ta upp i dessa sammanhang är Maurice Sendaks Till vildingarnas land från 1963. Precis som i En stackars liten haj finns det en berättelse i mitten som är relativt rak och konsekvent. Det finns inget i Max själva resa som är ambivalent. Nikolajeva skriver:

Som jag redan antytt är symmetrisk indikativ en ganska okomplicerad form. Vi tillämpar denna modalitet både på så kallade realistiska och icke-realistiska genrer. När vi läser Tant Grön, tant Brun och tant Gredelin, Totte- eller Emma-böcker, Alfons Åberg, Max eller Pulvret kan vi relatera till såväl ord som bilder och säga: detta är sant (eller kan åtminstone vara sant), jag känner igen miljöer och personer, händelserna är rimliga, och så vidare. När vi läser böcker som Tomtebobarnen, Blomsterfesten i täppan, Sagan om Pelle Kanin, eller Polly äter sylt säger vi: detta är inte sant, det finns inga tomtar, jag vet att blommor och djur talar inte och har inte kläder, men inom genrens konventioner, inom fiktionens ramar är detta sant och rimligt (2000:234).

Däremot är ikonotexten i början, när en skog växer i Max rum, och i slutet, när hans mat fortfarande är varm trots att han har varit borta i två år, ambivalent. Det finns inte tillräckligt med belägg i berättelsen fram till dess för att kunna säga att en växande skog i ett rum tillhör det normala i den aktuella fiktionsvärlden. Vad gäller slutet så är det faktum att maten fortfarande är varm när Max kommer tillbaka en indikation på att händelserna inte bör tolkas bokstavligt. En vuxen tolkar antagligen berättelsen som att Max har dagdrömt hela äventyret som ett sätt att bearbeta sin ilska och sin frustration, medan ett barn nog tolka händelserna mimetiskt, alltså som att de har förekommit (även om barnet säkert anar att det finns flera skikt i berättelsen). En detalj, påpekar Nikolajeva som stödjer en mimetisk läsning är att 
månen under historiens gång går från att vara halv till att vara hel, vilket antyder att mer än ett par minuter har passerat (2000:239).

En skillnad mellan Till vildingarnas land och En stackars liten haj är att det i den förra i början och i slutet inte finns någon motsättning mellan text och bild. Som Ulla Rhedin skriver: "Tillsammans påstår bild och text att djungeln växer och att ett hav brusar fram med en egen båt till Max, så att han kan ge sig iväg” (2001:199). I En stackars liten haj finns en viss ambivalens i de första bilderna, som gestaltar pojkens rädsla för hajar på ett okonventionellt sätt, genom att placera hajarna i samma bildrum som pojken men på ett sätt som gör att en vuxen förstår (och även kan förklara för ett litet barn) att de inte finns där "på riktigt”. En konventionell lösning hade varit att exempelvis placera hajarna i en tankebubbla eller liknande. I Gustavssons gestaltning står det klart att rädslan bokstavligen har tagit över pojkens tillvaro. I slutet är, som tidigare nämnts, ordens och bildens modalitet skiftande. Texten säger en sak, bilden antyder en annan.

En annan sak som ger upphov till ambivalenta läsningar är det faktum att det görs kopplingar tillbaka till den "verkliga” världen. Detta är inte ett ovanligt grepp i fantastiska berättelser för barn. Ett känt exempel är Astrid Lindgrens roman Mio min Mio (1954), som ofta betecknas som fantasy, även om Lindgren-kännaren Vivi Edström betecknar den som en ”sagoroman” (1997:98). När Bosse förvandlats till Mio och kommit till Landet i Fjärran så upptäcker han att allt han ser har stora likheter med de sagor han är bekant med sedan tidigare. Edström skriver: "Vi befinner oss inte i sagans omedelbara, naiva värld utan i en berättelse som skapar medvetenhet kring sagans tradition” (1997:101). En annan dubbelprojicering - förutom den mellan den lästa sagan och den levda sagan - är den mellan Stockholms-tillvaron och livet i Landet i Fjärran. Edström pekar på det när hon nämner likheten mellan rosorna i Fader Konungens rosengård och de törnrosor som växte i Vaxholm, en av de lyckliga dagar när Bosse fick följa med sin vän Benka och hans far till deras sommarställe. Det finns fler sådana analogier: Likheterna mellan Benkas far och konungen, mellan Benka själv och Jum-Jum, och så vidare. Allt detta, tillsammans med andra element i romanen, skapar en ambivalens, där berättelsen kan läsas dels mimetiskt, dels symboliskt, som det övergivna barnets önskedröm, närt av sagor och enstaka upplevelser av skönhet och vänlighet. I En stackars liten haj finns samma tillvägagångssätt hos pojken, fast här förmedlas det via bilden. Det är den tidigare nämnda bläckfisken som får fungera som en sorts "ankare” i verkligheten medan äventyret pågår. Sammanlagt återfinns bläckfisken på sex uppslag, av vilka det första är i pojkens rum, som en leksak upphängd i taket. Under pojkens äventyr ingår den i en icke-verbal parallellberättelse som går ut på att en flicka kör den i en skottkärra till havet. Den finns också med i den labyrint av rör som vi får ta del av på Vattenverket. Bläckfisken skapar en subtil ambivalens som öppnar upp berättelsen.

\section{Fantasin som läkande kraft}

Oavsett vad vi kategoriserar en icke-realistisk berättelse som: drömtext, fantasy, saga, eller något annat, så skapar den möjligheter för tolkningar på olika plan. Man kan alltid se den fantastiska delen i relation till den realistiska delen, eller, om berättelsen utspelar sig helt i en fantastisk tillvaro, dra paralleller mellan vår värld och fiktionsvärlden. Framförallt när det gäller fantastiska berättelser för mindre barn ligger det nära till hands, som tidigare påpekats, 
att lägga tolkningen nära barnets verklighet, eftersom dess övergång från verklighet till fantastik ofta går genom drömmen eller dagdrömmen. Barn, liksom även vuxna människor, använder sig av fantasi för att bearbeta svåra upplevelser, rädslor eller sorg. Med hjälp av fantasyberättelser och sagor kan barnet få hjälp med en sådan bearbetning, och kanske känna sig mindre ensamt. Identifikation är en viktig faktor för barnlitteraturen. Som Ann Boglind och Anna Nordenstam skriver: ”Fantasytexter inbjuder sina läsare till fantasivärldar där det blir möjligt för dem att bearbeta sina egna drömmar och problem genom att själva fantisera vidare” (2010:280). Bruno Bettelheim har skrivit följande om sagans funktion:

Från sin jordiska och enkla början går sagan vidare till fantastiska händelser. Men hur stora omvägar berättelsen än tar, går den - till skillnad från barnets naiva sinne eller en dröm - aldrig vilse. Efter att ha tagit barnet med sig på en resa till undrens värld går färden till slut på det mest lugnande sätt tillbaka till verkligheten. Barnet får på så sätt lära sig vad det mest av allt behöver veta på detta stadium av sin utveckling: att det inte är till förfång att låta fantasin bära iväg med en, bara man inte stannar kvar i den för alltid. I slutet på sagan återvänder hjälten till verkligheten - en lycklig verklighet men utan förtrollning.

Liksom vi vaknar uppfriskade ur våra drömmar, bättre rustade att möta vardagens uppgifter, slutar sagan med att hjälten vänder tillbaka till den verkliga världen mycket bättre rustad att bemästra sitt liv ([1976] 1989:77).

På många sätt stämmer Bettelheims ord in på situationen i En stackars liten haj, men inte helt. Exempelvis finns det ingen tydlig gräns mellan förtrollning och verklighet, i och med att pojkens dröm äger rum i verkligheten och färgas av den. Om man gör en mimetisk tolkning och läser berättelsen som att hela äventyret med hajen verkligen har inträffat, då försvinner ju inte magin för att pojken återvänder hem. Då vet han att det i hans tillvaro finns talande hajar, utomjordingar och björnar i kostym som åker buss. Åtminstone finns de på kvällen. På samma sätt är det exempelvis i Lindgrens "I Skymningslandet” - Göran vet även på dagen att skymningstimmen inträffar varje kväll, och att staden blir magisk då. Det är alltså inte alltid så lätt att dra en skarp skiljelinje mellan verklighet och magi, åtminstone inte i fantasy för mindre barn.

Sarah Gilead skriver följande om återvändandet till verkligheten i Sendaks böcker Till Vildingarnas land och I nattköket (1970):

Like The Wizard of $\mathrm{Oz}$, two of Maurice Sendak's picture books for children, Where the Wild Things Are and In the Night Kitchen, enclose fantasy narratives in realistic frames whose closural segments confirm the fantasies' therapeutic function. The dissolution of the dreamworld implies that the dreamer has introjected the messages conveyed and can now achieve intrapsychic and communal integration. In each of these works the child hero enters a fantastic kingdom, performs symbolic tasks, and returns to his own room (1991:280).

Både Bettelheim och Gilead pekar på återvändandet som en avgörande del av berättelsen. I En stackars liten haj återvänder huvudpersonen stärkt och bekräftad till verkligheten. I sin fantasi har han övervunnit sin rädsla och vänt på situationen: den han fruktade mest fick vara den rädda, och han den starka och beslutsamma som löste situationen. Det lyckliga slutet innebär ett återvändande till modern, både för hajen och för honom själv: "Han tänkte på hajar och mammor och på hur skönt det var att bada” (sista sidan). Det visar på en stor skillnad mellan En stackars liten haj och flera bilderböcker med liknande struktur, som 
exempelvis Till vildingarnas land: I den förra finns ingen destruktiv relation till föräldrarna (och specifikt modern) som pojken måste bearbeta. Tvärtom verkar pojkens mor, även om vi inte får se henne i bild, vara en närvarande och förstående förälder. Äventyret med hajen är något som pojken måste klara av på egen hand, utan henne. Man kan se det som en sorts frigörelse- eller mognadsprocess.

\section{Avslutning}

En stackars liten haj är en bilderbok om att bearbeta rädslor med hjälp av sin fantasi. Den är berättad ur ett barnperspektiv, och det är ett barns föreställningar om den okända, nattliga världen som får styra gestaltningen. Bilderboken har en särskild förmåga att gestalta känslor, vilket Nikolajeva påpekar: "Emotions are by definition non-verbal, and language can never convey an emotion effectively. This is where picturebooks offer a unique opportunity to engage with empathy and mind-reading circumventing the inadequacy of language” (2013: 252). Detta gör också, enligt Nikolajeva att bilderböcker hjälper barn att lära sig att identifiera sig med andra och känna empati med dem:

One potential way of fostering empathy in young children is through picturebooks. Like all fiction, picturebooks represent fictional characters' emotions as well as their interpretation of each other's emotions. However, unlike novels, picturebooks evoke our emotional engagement through images as well as words and, moreover, through amplification of words by images (2013: 249).

Ord och bild kompletterar varandra i En stackars liten haj men ifrågasätter emellanåt varandra också på ett sätt som skapar många olika tolkningsmöjligheter, exempelvis vad gäller relationen mellan verklighet och dagdröm. Denna ambivalens går dock aldrig ovanför barnets huvud, utan visualiseras på ett sätt som både barn och vuxna kan ta till sig. När bild ifrågasätter text på ett kreativt sätt kan en magisk stämning uppkomma med små medel och utan att avlägsna sig alltför lång bort ifrån barnets bekanta verklighet. På det sättet kan barnet i trygghet utforska de delar av berättelsen, och av sig själv, som kan kännas problematiska och skrämmande. Barnet ges verktyg att själv använda fantasin på ett konstruktivt sätt, för att bearbeta rädslor eller sorger. Genom att läsa om och se bilder av andra barn i liknande situationer - oavsett om dessa barn och situationer är fiktiva eller ej - förstår barnet att det inte är ensamt om sina tankar och känslor, och att känslor av sorg eller rädsla inte är farliga eller konstiga, utan en del av livet.

\section{Referenser}

Bettelheim, Bruno (1989), Sagans förtrollade värld. Stockholm: Norstedts.

Boglind, Ann \& Nordenstam, Anna (2011), Från fabler till manga. Malmö: Gleerups.

Edström, Vivi (1997), Astrid Lindgren och sagans makt. Stockholm: Rabén \& Sjögren.

Gilead, Sarah (1991), ”Magic Abjured: Closure in Children's Fantasy Fiction”, PMLA 106, s. 277- 293.

Jesset, Aurore \& Korthues, Barbara (2008), Kom tillbaka, Nenne. Bromma: Opal.

Lindgren, Astrid, Törnqvist, Marit (1994), I Skymningslandet. Stockholm: Rabén \& Sjögren.

Lööf, Jan (1978), Pelles ficklampa. Stockholm: Carlsen.

Nikolajeva, Maria (2000), Bilderbokens pusselbitar. Lund: Studentlitteratur. 
Nikolajeva, Maria (2012), "The Development of Children's Fantasy”, i Edward James \& Farah Mendelsohn (red), The Cambridge Companion to Fantasy Literature. Cambridge: Cambridge University Press, ss. 50-61.

Nikolajeva, Maria (2013), "Picturebooks and Emotional Literacy”, The Reading Teacher vol. 106, no. 4, s. 249-254.

Nikolajeva, Maria (2017), Barnbokens byggklossar. Lund: Studentlitteratur.

Propp, Vladimir (1984), Theory and History of Folklore. Översättning: Ariadna Y. och Richard P. Martin. Red. Anatoly Liberman. Manchester: Manchester University Press.

Rhedin, Ulla (2001), Bilderboken: På väg mot en teori. Stockholm: Alfabeta.

Sandberg, Inger \& Sandberg, Lasse (2008), Tummen tittar på natten. Karlstad: Tre Sandberg AB.

Sandén, Mårten och Gustavsson, Per (2014), En stackars liten haj. Stockholm: Rabén \& Sjögren.

Sendak, Maurice (1978), Till vildingarnas land. Stockholm: Bonniers.

Shavit, Zohar (1980), "The Ambivalent Status of Texts; the Case of Children's Literature”, Poetics Today, vol. 1, no. 3, s. 75-86. www.jstor.org/stable/1772412

Svensson, Thomas (2006), Busiga Bebbens nattbok. Stockholm: Bonnier Carlsen.

Wall, Barbara (1991): The Narrator's Voice; The Dilemma of Children's Fiction. New York: Palgrave Macmillan.

Westin, Boel (2008), '”'Ej verklighet men mer än verklighet...' Drömtexter i barnlitteraturen”, i Maria Andersson \& Elina Druker (red.), Barnlitteraturanalyser. Lund: Studentlitteratur, s. 72- 81.

\section{Bildförteckning}

Bild 1 samt bild 2 med tillstånd av Per Gustavsson. 